\title{
$\mu$-Opioid Receptors are not Involved in Acute Cocaine-Induced Locomotor Activity nor in Development of Cocaine-Induced Behavioral Sensitization in Mice
}

\author{
Heidi MB Lesscher', Michiel Hordijk', Natalia P Bondar², Olga V Alekseyenko², J Peter H Burbach', \\ Jan $M$ van Ree' and Mirjam AFM Gerrits*,' \\ 'Department of Pharmacology and Anatomy, Rudolf Magnus Institute of Neuroscience, UMC Utrecht, Stratenum, Universiteitsweg I O0, Utrecht, \\ The Netherlands; ${ }^{2}$ Institute of Cytology and Genetics, SD RAS, Novosibirsk, Russia
}

\begin{abstract}
Although $\mu$-opioid receptors have been extensively investigated for their role in drug reinforcement, little is known about the contribution of these receptors to the acute and sensitized locomotor response to cocaine. In this study $\mu$-opioid receptor involvement in acute cocaine-induced locomotor activity and in the development of cocaine-induced behavioral sensitization was evaluated using $\mu$ opioid receptor knockout mice and chronic naltrexone (NTX) pretreatment as models. In addition, co-administration of the specific $\mu$ opioid receptor antagonist CTOP with repeated saline or cocaine injections was used to establish the involvement of $\mu$-opioid receptors in sensitization to the locomotor stimulant effects of cocaine. The acute locomotor response to cocaine (3, 10,20 , or $30 \mathrm{mg} / \mathrm{kg}$ i.p.) of $\mu$ opioid receptor knockout or chronic NTX pretreated mice was not different from the cocaine response of their respective controls. With respect to cocaine-induced behavioral sensitization, induced by daily injections of $20 \mathrm{mg} / \mathrm{kg}$ cocaine for II subsequent days, $\mu$ opioid receptor knockout mice developed behavioral sensitization to the locomotor stimulant effects of cocaine (challenge $10 \mathrm{mg} / \mathrm{kg}$ i.p.) comparable to wild-type littermates and the $\mu$-opioid receptor antagonist CTOP did not affect cocaine-induced sensitization either However, mice that were pretreated with NTX exhibited augmented cocaine-induced behavioral sensitization relative to placebo pretreated controls, which may be ascribed to increased $\delta$-opioid receptor levels as has been described for chronic NTX pretreated mice. The present findings suggest that $\mu$-opioid receptors are not required for the acute locomotor response to cocaine nor are they essential for the development of cocaine-induced behavioral sensitization.

Neuropsychopharmacology (2005) 30, 278-285, advance online publication, I4 July 2004; doi: I 0.1038/sj.npp. 1300529
\end{abstract}

Keywords: sensitization; cocaine; $\mu$-opioid; $\delta$-opioid; receptor; mice

\section{INTRODUCTION}

Repeated intermittent exposure to cocaine enhances the locomotor stimulant effects of cocaine upon a subsequent exposure. This phenomenon, behavioral sensitization to the motor stimulant effects of drugs, is thought to reflect longterm adaptations to chronic drug exposure that may underlie certain aspects of drug addiction (Robinson and Berridge, 2000). A single exposure to cocaine can be sufficient to induce long-lasting sensitization to the locomotor stimulant effects of cocaine (Vanderschuren

*Correspondence: Dr MAFM Gerrits, Department of Pharmacology and Anatomy, Rudolf Magnus Institute of Neuroscience, UMC Utrecht, Stratenum, Universiteitsweg 100, 3584 CG Utrecht, The Netherlands, Tel: + 3130 2538842, Fax: + 3130 2538I55,

E-mail: m.a.f.m.gerrits@med.uu.nl

Received 22 December 2003; revised 19 May 2004; accepted 18 June 2004

Online publication: 21 June 2004 at http://www.acnp.org/citations/ Npp062 $10403537 /$ default.pdf et al, 1999), possibly through long-term potentiation of dopamine neurons in the ventral tegmental area (VTA) (Ungless et al, 2001). Repeated intermittent pre-exposure to cocaine also facilitated the subsequent acquisition of cocaine self-administration (Horger et al, 1990; Piazza et al, 1990). Furthermore pre-exposure to, for example, amphetamine, cocaine, and morphine enhanced the conditioned motivational effects of the respective drug (Lett, 1989; Shippenberg and Heidbreder, 1995a). Thus, repeated exposure to drugs of abuse induces long-term adaptations, which contribute to sensitization to the locomotor stimulant and motivational effects of these drugs.

Involvement of endogenous opioid systems in drug reinforcement has been demonstrated repeatedly in laboratory animals (Herz, 1997; Van Ree et al, 1999). Opioid antagonists reduce cocaine and ethanol self-administration (De Vry et al, 1989; Froehlich et al, 1990; Kornet et al, 1991; Kuzmin et al, 1997; Stromberg et al, 1998), primarily through $\mu$-opioid receptors in the VTA (Ramsey et al, 1999). Endogenous opioid systems have also been implicated in 
behavioral sensitization induced by psychostimulants. For example, the nonselective opioid antagonist naltrexone (NTX) prevented the development of cocaine-induced behavioral sensitization (Sala et al, 1995). The selective $\delta$ opioid receptor antagonist naltrindole blocked the development, but not the expression, of sensitization to the locomotor stimulant effects of cocaine (Heidbreder et al, 1993a, 1996). Moreover, sensitization to the conditioned effects of cocaine was prevented when naltrindole was given together with repeated cocaine injections (Shippenberg and Heidbreder, 1995b). Effects of $\kappa$-selective opioid receptor agonists, both exogenous and endogenous, upon behavioral sensitization have been reviewed elsewhere (Shippenberg and Rea, 1997). In short, sensitization to the conditioned effects of cocaine or amphetamine, as apparent after preexposure to a psychostimulant, was abolished when $\kappa$ opioid receptor agonists were administered in combination with the psychostimulant (Shippenberg et al, 1996). In addition, $\kappa$-opioid receptor agonists reduced sensitization to the locomotor stimulant effects of cocaine (Heidbreder et al, 1993b, 1995), but (Vanderschuren et al, 2000). Taken together, these studies indicate that $\delta$ - and $\kappa$-opioid receptors are involved in the development of cocaineinduced behavioral sensitization. In contrast, little is known about the role of $\mu$-opioid receptors in sensitization to the (locomotor) effects of cocaine. Interestingly, data from a recent study suggested that $\mu$-opioid receptors might also contribute to cocaine-induced behavioral sensitization (Yoo et al, 2003).

The aim of this study was to establish the involvement of $\mu$-opioid receptors in acute cocaine-induced locomotor activity and in cocaine-induced behavioral sensitization. The possible role of $\mu$-opioid receptors in the acute locomotor response to cocaine and in cocaine-induced behavioral sensitization was investigated using $\mu$-opioid receptor knockout mice, co-administration of the $\mu$-opioid receptor selective antagonist CTOP (Hawkins et al, 1989), and by means of chronic NTX pretreated mice. Chronic NTX pretreatment was included in this study because chronic exposure of mice to NTX results in an increase in $\mu$ opioid receptor binding sites, although $\delta$-opioid receptor binding is also increased by this pretreatment albeit to a lower extent and upregulation of $\kappa$-opioid receptors after chronic NTX exposure is restricted to cortical regions (Yoburn et al, 1988; Lesscher et al, 2003).

\section{MATERIALS AND METHODS}

\section{Animals}

Male mice, either C57Bl/6Jico mice (Charles River, $l^{\prime}$ Arbresle, France) or $\mu$-opioid receptor knockout and wild-type mice derived from heterozygous breeding (GDL, Utrecht), aged 2-3 months were group housed (2-4) in extended Macrolon ${ }^{(}$type I cages with water and food pellets available ad libitum. Environmental conditions were controlled $\left(22^{\circ} \mathrm{C}\right.$ and $50 \%$ humidity; lights on at 0700 and lights off at 1900, GDL Utrecht University). The experimental procedures were approved by the Ethical Committee for Animal Experiments of the University Medical Center Utrecht.

\section{$\mu$-Opioid Receptor Knockout Mice}

The $\mu$-opioid receptor knockout and wild-type mice used for this experiment have been described previously and were on a mixed 129Sv/C57Bl6 background (Schuller et al, 1999). No detectable binding of $\left[{ }^{3} \mathrm{H}\right] \mathrm{DAMGO}$ or $\mu$-opioid receptor transcript was present in $\mu$-opioid receptor knockout mice and there is no evidence for compensatory changes in other opioid receptor subtypes: binding to $\delta$ opioid receptor subtypes was comparable between genotypes and $\delta$ - and $\kappa$ - and ORL-1 receptor mRNA levels were also unchanged (Schuller et al, 1999). Wild-type $(+/+)$ and homozygous knockout $(-I-)$ mice were obtained from heterozygous breeding. The mice used in the present study were on a C57Bl6/Jico background after 6-7 backcrossings to C57Bl6/Jico mice (Charles River, l'Arbresle, France). The mice were genotyped by PCR on genomic DNA isolated from tail tips. The mutant product was $700 \mathrm{bp}$, the wild-type product $525 \mathrm{bp}$; the three primers used were outside the mutation site ( $5^{\prime}$ GAC TTT CCT GGC TGA TGC AAA CAA CCT $\left.3^{\prime}\right)$, within the mutation site ( $5^{\prime}$ CAT GGT TCT GAA TGC TTG CTG CGG ACT $3^{\prime}$ ) and within the neomycin box (5' CTA CCT GCC CAT TCG ACC ACC AA $3^{\prime}$ ).

\section{Chronic NTX Treated Mice}

At least 1 week after transportation, C57Bl/6Jico mice from Charles River (L'Arbresle, France) received a pellet containing $15 \mathrm{mg}$ NTX or a corresponding placebo pellet, which was implanted subcutaneously in the nape of the neck under isoflurane anesthesia $\left(2 \% / 53 \% \mathrm{~N}_{2} \mathrm{O} / 45 \% \mathrm{O}_{2}\right)$ (day 1$)$. NTX and placebo treatments were randomly assigned and mice of both treatment groups were housed together (two of both per cage). On day 8 the pellet was removed $(2 \%$ isoflurane $/ 53 \% \mathrm{~N}_{2} \mathrm{O} / 45 \% \mathrm{O}_{2}$ ). All experiments described here commenced $48 \mathrm{~h}$ after pellet removal, that is, on day 10 .

\section{Acute Cocaine-Induced Locomotor Activity}

Experiment 1. $\mu$-Opioid receptor knockout mice; experiment 2. Chronic NTX treated mice. Clear plexiglass cylinders of $20 \mathrm{~cm}$ in diameter and $30 \mathrm{~cm}$ in height were used as open fields. The mice were allowed to acclimatize to the experiment room for at least $1 \mathrm{~h}$ prior to placement in the open field. The mice were then placed in the open field and motor activity was monitored for $1 \mathrm{~h}$. Thereafter, saline was injected i.p. and the mice were monitored for another hour. Finally, cocaine was injected i.p. $(3,10,20$, or $30 \mathrm{mg} / \mathrm{kg})$ after which the mice were returned to the open field and their locomotor activity was determined for another $30 \mathrm{~min}$. During the total $2.5 \mathrm{~h}$ of the experiment, the activity pattern of the mice was tracked and analyzed for the total distance moved in the open field per 5 min intervals using Ethovision Color-Pro 2.3 software (Noldus Information Technology, Wageningen, NL). $N=6$ for 3,20 , and $30 \mathrm{mg} / \mathrm{kg}$ treatment groups. $N=8$ for the $10 \mathrm{mg} / \mathrm{kg}$ cocaine treatment group of the $\mu$-opioid receptor knockout experiment. $N=10$ for the $10 \mathrm{mg} /$ $\mathrm{kg}$ cocaine treated chronic NTX or placebo pretreated groups.

\section{Cocaine-Induced Behavioral Sensitization}

Experiment 3. Cocaine-induced behavioral sensitization in wild-type mice. In total, $16 \mathrm{C} 57 \mathrm{Bl} / 6 \mathrm{Jico}$ mice were 
randomly assigned to either cocaine or saline treatment groups. During 11 days the mice received a daily i.p. injection of either cocaine $(20 \mathrm{mg} / \mathrm{kg})$ or saline. At $72 \mathrm{~h}$ after the last cocaine or saline injection, the mice were transported and allowed to acclimatize to the experiment room for at least $1 \mathrm{~h}$. Thereafter, the mice were placed for the first time in the open field as described. During the first hour in the field the locomotor activity was measured to monitor the adaptation of the mice to the novel environment. Subsequently, all mice received a saline injection (i.p.) after which they were returned to the open field and monitored for another hour. Thereafter, all mice received a cocaine challenge $(10 \mathrm{mg} / \mathrm{kg}$ i.p.) and their locomotor activity in the open field was determined during $30 \mathrm{~min}$. The distance moved in the open field was measured as described above.

Experiment 4. $\mu$-Opioid receptor knockout and wild-type mice. At 2-3 months of age the behavioral sensitization commenced as described for experiment 3. Mice of both genotypes (wild-type $+I+$ and $\mu$-opioid receptor knockout mice $-/-$ ) were randomly assigned to either saline or cocaine treatment groups. Group sizes were either seven mice for the $+I+$ saline treatment group or eight mice for $+I+$ cocaine, $-I-$ saline, and $-I-$ cocaine treatment groups.

Experiment 5. CTOP co-administration. For this experiment 32 male C57Bl/6JIco mice from Charles River (L'Arblesle, France) were used. After transportation, the mice were allowed to acclimatize for at least 1 week before the behavioral sensitization commenced. The mice were randomly assigned to one of four treatment groups: placebo/saline, placebo/cocaine, CTOP/saline, or CTOP/ cocaine. CTOP $(1 \mathrm{mg} / \mathrm{kg})$ or placebo was administered i.p. $30 \mathrm{~min}$ prior to the daily saline or cocaine injections (coadministration). The $1 \mathrm{mg} / \mathrm{kg}$ dose for CTOP was chosen based on a previous reward-relevant study, which demonstrated effective reduction of alcohol consumption by both 0.1 and $1 \mathrm{mg} / \mathrm{kg}$ CTOP (Kim et al, 2000). Further procedures were similar to those described for experiment $3 . N=8$ per treatment group.

Experiment 6. Effects of chronic NTX pretreatment upon cocaine-induced behavioral sensitization. For this experiment mice were, prior to the behavioral sensitization protocol, pretreated with NTX or placebo by subcutaneous implanted pellets as described above for experiment 2. The sensitization protocol (see experiment 3) commenced $48 \mathrm{~h}$ after removal of the pellet, that is, on day $10 . N=8$ for placebo/saline, placebo/cocaine, NTX/saline, and NTX/ cocaine treatment groups.

\section{Drugs}

Cocaine (cocaine-HCl, OPG, Utrecht, The Netherlands) and CTOP (Tocris, Bristol, UK) were dissolved in saline, control mice received saline injections. Cocaine, CTOP, and saline were injected i.p. in a volume of $5 \mathrm{ml} / \mathrm{kg}$. NTX and corresponding placebo pellets (Research Triangle Institute,
North Carolina, USA) were implanted subcutaneously in the nape of the neck as described above.

\section{Statistical Analysis}

For statistical analyses SPSS10.1 was used. Open field activity is expressed as distance moved in $5 \mathrm{~min}$ intervals. Analyses of variance (ANOVAs) with repeated measurements were used to analyze the data with distance moved as the dependent variable. For the acute experiment only the locomotor activity data for the $30 \mathrm{~min}$ after cocaine injection was analyzed with genotype $(+/+$ or $-I-$, experiment 1) or pretreatment (placebo or NTX, experiment 2) as factors. For the sensitization experiment, the data for the first hour, the hour after saline injection and the $30 \mathrm{~min}$ after cocaine challenge were analyzed separately. The independent factors were treatment (saline or cocaine) and either genotype $(+I+$ or $-I-$, experiment 4$)$, coadministration (placebo or CTOP, experiment 5), or pretreatment (placebo or NTX, experiments 6). When appropriate, post hoc analyses were performed using Student's $t$-tests. The data are expressed as mean \pm SEM distance travelled in $5 \mathrm{~min}$ intervals in centimetres. Statistical significance was accepted at $P<0.05$.

\section{RESULTS}

\section{Acute Cocaine-Induced Locomotor Activity}

Experiment 1. Acute locomotor response to cocaine in $\mu$ opioid receptor knockout vs wild-type mice. After $2 \mathrm{~h}$ adaptation to the open field, the mice received $3,10,20$, or $30 \mathrm{mg} / \mathrm{kg}$ cocaine i.p. There were no differences between wild-type and $\mu$-opioid receptor knockout mice during habituation or during the hour after saline injection (data not shown). The dose-response curve for cocaine-induced locomotor activity of $\mu$-opioid receptor knockout mice and wild-type mice is shown in Figure 1. Cocaine increased the locomotor activity of both $\mu$-opioid receptor knockout and wild-type mice in the open field in a dose-dependent way (dose effect $\mathrm{F}(3,48)=31, P<0.001$ ). The genotypes were comparable in their response to cocaine because there was no significant time $\times$ genotype $\times$ dose interaction, no significant effect of genotype, nor was there a genotype $\times$ dose effect.

Experiment 2. Effects of chronic NTX pretreatment upon acute cocaine-induced locomotor activity. After $2 \mathrm{~h}$ adaptation to the open field, the mice received $3,10,20$, or $30 \mathrm{mg} / \mathrm{kg}$ cocaine i.p. There were no differences between placebo and chronic NTX pretreated mice during habituation or the hour after saline injection (data not shown). The dose-response curve for cocaine-induced locomotor activity of chronic NTX and placebo pretreated mice is depicted in Figure 2. Cocaine increased the locomotor activity of the mice in this experiment in a dose-dependent manner as is apparent from a significant dose effect $(\mathrm{F}(3,47)$ $=45, \quad P<0.001)$ and a significant time $\times$ dose interaction $(\mathrm{F}(15,235)=4.2, P<0.001)$. Further, a significant time $\times$ pretreatment $\times$ dose interaction was observed $(\mathrm{F}(15,235)=2.9, P<0.001)$, which was caused by a significant time $\times$ pretreatment interaction within the 


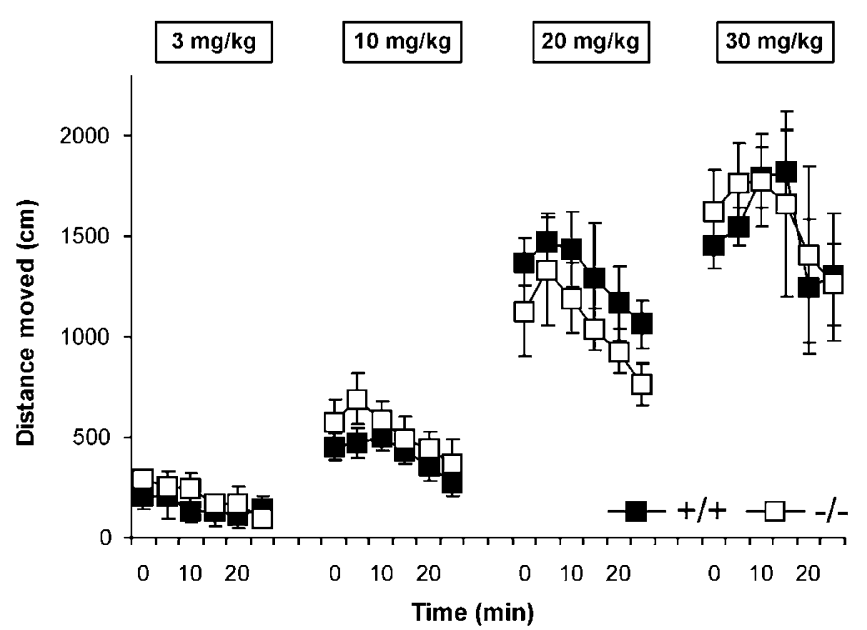

Figure I Acute cocaine-induced locomotor activity for $\mu$-opioid receptor knockout $(-/-)$ and wild-type $(+/+)$ mice. The distance moved in $\mathrm{cm}$ during $30 \mathrm{~min}$ subsequent to $3,10,20$, or $30 \mathrm{mg} / \mathrm{kg}$ cocaine administration i.p. is shown for both genotypes. $N$ per genotype was 6 for 3,20 , or $30 \mathrm{mg} / \mathrm{kg}$ and $\mathrm{N}=8$ for $10 \mathrm{mg} / \mathrm{kg}$ cocaine.

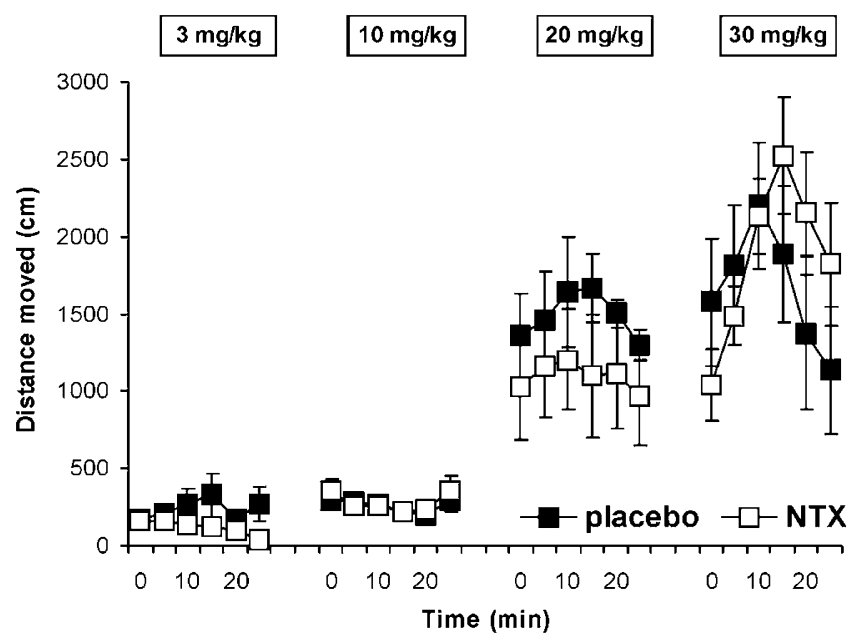

Figure 2 Effects of chronic NTX pretreatment upon the acute response to cocaine. The distance moved in $\mathrm{cm}$ during $30 \mathrm{~min}$ subsequent to 3,10 , 20 , or $30 \mathrm{mg} / \mathrm{kg}$ cocaine administration i.p. is shown for both pretreatment groups. $\mathrm{N}$ per NTX or placebo pretreatment group was 6 for 3,20 , or $30 \mathrm{mg} / \mathrm{kg}$ and $\mathrm{N}=10$ for $10 \mathrm{mg} / \mathrm{kg}$ cocaine.

$30 \mathrm{mg} / \mathrm{kg}$ cocaine dose group $(\mathrm{F}(5,50)=3.0, P<0.05)$. It appears that the response to cocaine is somewhat altered for the NTX pretreated mice as compared to the placebo controls (Figure 2).

\section{Cocaine-Induced Behavioral Sensitization}

Experiment 3. Cocaine-induced behavioral sensitization in wild-type mice. The locomotor activity in the open field and the response to a $10 \mathrm{mg} / \mathrm{kg}$ cocaine challenge of C57Bl/ 6)ico mice after repeated administration of $20 \mathrm{mg} / \mathrm{kg}$ cocaine or saline injections is shown in Figure 3.

During the first hour in the open field the activity of the mice declined (time $\mathrm{F}(11,143)=7.5, P<0.001$ ) and there was no effect of cocaine treatment upon the activity in the

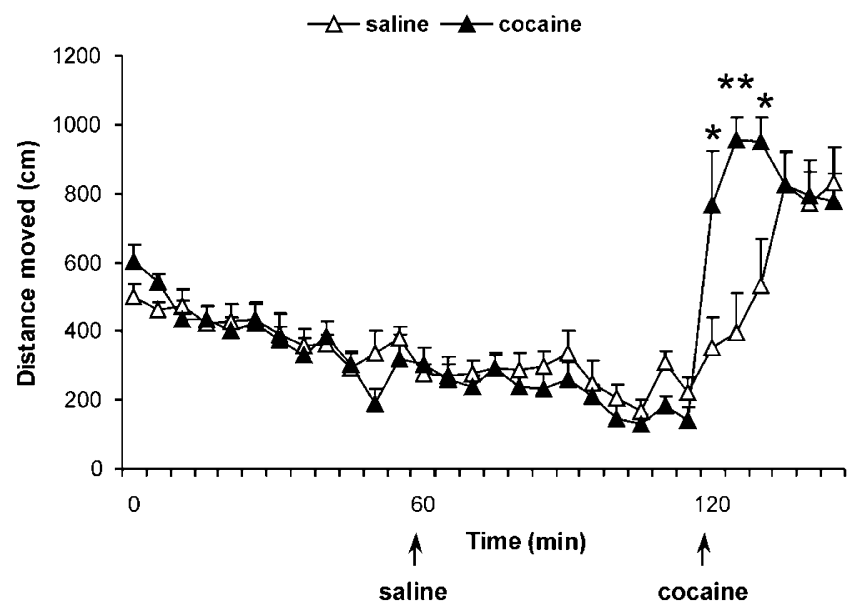

Figure 3 Development of behavioral sensitization in C57BI6/Jico mice. Sensitization was induced by repeated intermittent treatment of C57BI/ 6 lico mice with saline or cocaine $(20 \mathrm{mg} / \mathrm{kg})$ for I I days. The time course of the activity in the open field, $72 \mathrm{~h}$ after cessation of the sensitization protocol, is shown with I h adaptation to the field, followed by I $\mathrm{h}$ in the field after an i.p. saline injection and 30 min after an i.p. injection of $10 \mathrm{mg} / \mathrm{kg}$ cocaine. The activity in the open field is expressed in the total distance moved in centimetres during $5 \mathrm{~min}$ intervals. $N=8$ per treatment. $* P<0.05$, ** $P<0.01$, significant difference between saline and cocaine treated mice.

unfamiliar open field. Subsequent to saline administration, a further decline in the activity of the mice was apparent (time $\mathrm{F}(11,143)=3.2, P<0.01$ ) without cocaine treatment effects. After the $2 \mathrm{~h}$ of adaptation to the open field, $10 \mathrm{mg} /$ $\mathrm{kg}$ cocaine was administered and induced an increase in the locomotor activity of the mice (Figure 3 ). The cocaine and saline treated mice responded differentially to the $10 \mathrm{mg} / \mathrm{kg}$ cocaine challenge, as is evident from a significant time$\times$ treatment interaction $(\mathrm{F}(5,65)=4.8, P<0.01)$ and an overall effect of treatment $(\mathrm{F}(1,13)=4.9, P<0.05)$. Post hoc analyses revealed significant differences between saline and cocaine treated mice for the first $15 \mathrm{~min}$ after the $10 \mathrm{mg} / \mathrm{kg}$ cocaine challenge was administered; $P<0.05,<0.01$, and $<0.05$ for the locomotor activity during $0-5,5-10$, and $10-$ $15 \mathrm{~min}$ after cocaine injection, respectively. This sensitization protocol was subsequently used for the experiments 4 , 5 , and 6.

Experiment 4. Cocaine-induced behavioral sensitization in $\mu$-opioid receptor knockout and wild-type mice. Locomotor activity and the response to a cocaine challenge of $\mu$-opioid receptor knockout mice $(-I-)$ and wild-type controls $(+I+)$ are shown in Figure 4.

The locomotor activity of $\mu$-opioid receptor knockout and wild-type mice reduced during the first hour in the open field (effect of time: $\mathrm{F}(11,297)=10, P<0.001)$. During the $60 \mathrm{~min}$ after saline injection, the locomotor activity of the mice did not further decline and a significant time$\times$ genotype interaction was observed $(\mathrm{F}(11,297)=2.0$, $P<0.05)$ : the $\mu$-opioid receptor knockout mice were less active as compared to wild-type mice 15-20, 35-40, and $40-45 \mathrm{~min}$ after saline injection $(P<0.05)$. There was no effect of treatment upon the activity of the mice in the open 


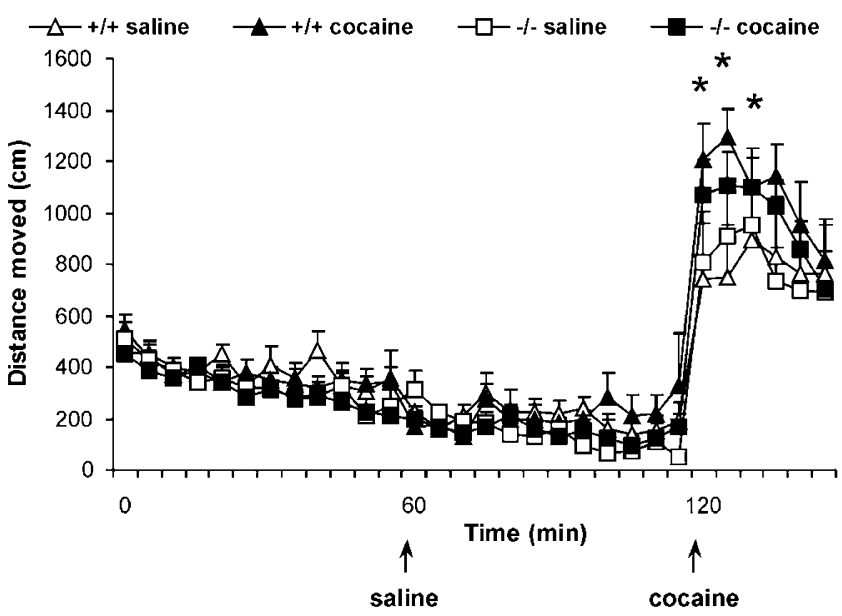

Figure 4 Behavioral sensitization in $\mu$-opioid receptor knockout mice $(-/-)$ and wild-type controls $(+/+)$. Sensitization was induced by repeated intermittent treatment with saline or cocaine $(20 \mathrm{mg} / \mathrm{kg})$ for II days. The time course of the activity in the open field, $72 \mathrm{~h}$ after cessation of the sensitization protocol, is shown with I h adaptation to the field, followed by I $\mathrm{h}$ in the field after an i.p. saline injection and $30 \mathrm{~min}$ after an i.p. injection of a $10 \mathrm{mg} / \mathrm{kg}$ cocaine challenge. The activity in the open field is expressed in the total distance moved in centimetres during 5 min intervals. $N=7-8$ per treatment per genotype. $* P<0.05$, significant difference between saline and cocaine treated subjects.

field and all mice were comparable in their locomotor activity just prior to cocaine injection.

The locomotor response to the $10 \mathrm{mg} / \mathrm{kg}$ cocaine challenge was augmented in cocaine treated mice as compared to saline treated mice, illustrating the occurrence of behavioral sensitization to cocaine (time $\times$ treatment $\mathrm{F}(5,135)=2.3, P<0.05)$. Subsequent Post hoc tests revealed that cocaine treated mice responded with a higher increase in locomotor activity as compared to saline treated mice during $0-5,5-10$, and $15-20$ min after the cocaine challenge was administered $(P<0.05)$. No genotype or genotype $\times$ treatment interaction was observed, suggesting that the development of cocaine-induced behavioral sensitization was comparable for $\mu$-opioid receptor knockout and wild-type mice. There was no difference between saline treated wild-type and $\mu$-opioid receptor knockout mice in their locomotor response to cocaine in the open field.

Experiment 5. Effects of CTOP co-administration upon cocaine-induced behavioral sensitization. In Figure 5 the locomotor activity and the locomotor response to a cocaine challenge is shown for mice, which received either CTOP or placebo co-administered with the repeated intermittent saline or cocaine injections.

During the first hour in the open field the mice reduced their activity (effect of time, $\mathrm{F}(11,308)=28, P<0.001$ ), indicative of adaptation to the open field. There was a significant co-administration $\times$ treatment effect upon the activity during the first hour in the open field $(\mathrm{F}(1,28)=6.8$, $P<0.05$ ), which was caused by higher locomotor activity of the CTOP/saline treated mice as compared to saline/saline and CTOP/cocaine treated mice. The locomotor activity declined further during the hour after saline injection (time

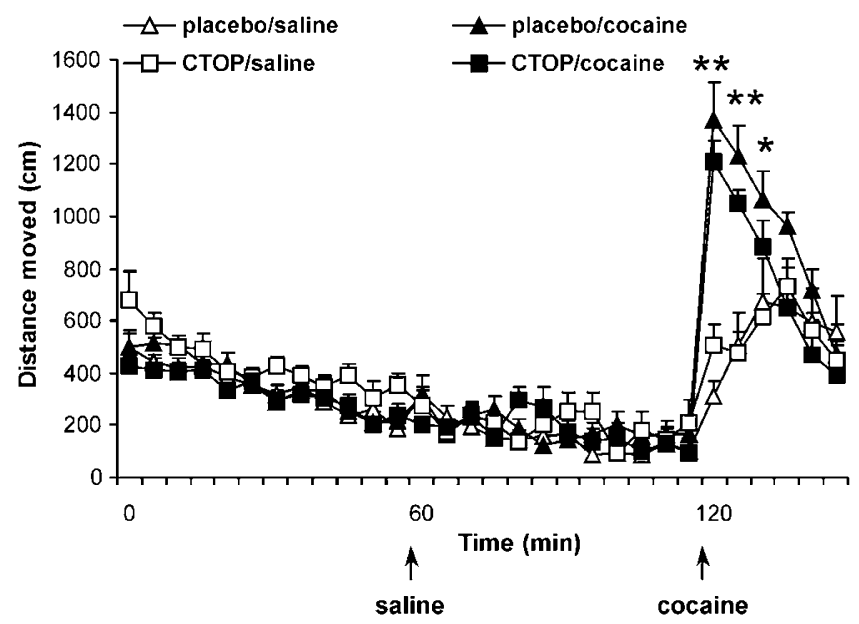

Figure 5 Effects of CTOP upon the development of cocaine-induced behavioral sensitization. CTOP or placebo were injected 30 min prior to repeated intermittent saline or cocaine $(20 \mathrm{mg} / \mathrm{kg})$ injections for II days (co-administration). The time course of the activity in the open field, $72 \mathrm{~h}$ after cessation of the sensitization protocol, is shown with I h adaptation to the field, followed by I $\mathrm{h}$ in the field after an i.p. saline injection and $30 \mathrm{~min}$ after injection of a $10 \mathrm{mg} / \mathrm{kg}$ cocaine challenge. The activity in the open field is expressed in the total distance moved in centimetres during $5 \mathrm{~min}$ intervals. $N=8$ per treatment (saline or cocaine) per co-administration (placebo or CTOP). $* P<0.01$, **P $<0.001$, significant difference between saline and cocaine treatment groups.

effect $\mathrm{F}(11,308)=4.9, P<0.001)$ and a significant time $\times$ co-administration $\times$ treatment effect was observed $(\mathrm{F}(11,308)=2.1, P<0.05)$, which as Post hoc tests revealed was caused by minor differences between groups. That is, 0-5 min after saline administration the saline/cocaine treated mice were more active than $\mathrm{CTOP} /$ cocaine treated mice $(P<0.05)$. Further, $20-25 \mathrm{~min}$ after saline was administered, $\mathrm{CTOP} /$ cocaine treated mice were more active than mice from the CTOP/saline group $(P<0.05)$ and 35$40 \mathrm{~min}$ after saline injection, the mice that received repeated $\mathrm{CTOP} /$ saline treatment were more active in the open field as compared to saline/saline treated mice $(P<0.05)$. All groups were comparable in their locomotor activity during the last intervals prior to cocaine administration.

Overall analysis of the locomotor activity of all groups during the $30 \mathrm{~min}$ after administration of the $10 \mathrm{mg} / \mathrm{kg}$ cocaine challenge dose revealed a significant time $x$ treatment (saline or cocaine) interaction $(F(5,140)=28$, $P<0.001$ ). Cocaine treated mice responded with a higher increase in locomotor activity to the $10 \mathrm{mg} / \mathrm{kg}$ cocaine challenge during $0-5,5-10$, and $10-15$ min after cocaine was injected $(P<0.001,<0.001$, and $<0.01)$. There was no effect of CTOP co-administration nor was there a significant time $\times$ co-administration $\times$ treatment interaction, suggesting that the $\mu$-opioid receptor antagonist CTOP did not affect the development of cocaine-induced behavioral sensitization. CTOP co-administration did not affect the acute locomotor response to cocaine as CTOP/saline treated mice were not significantly different in their response to cocaine from placebo/saline treated mice.

Experiment 6. Effects of chronic NTX pretreatment upon cocaine-induced behavioral sensitization. The locomotor activity in the open field and the response to a $10 \mathrm{mg} / \mathrm{kg}$ 


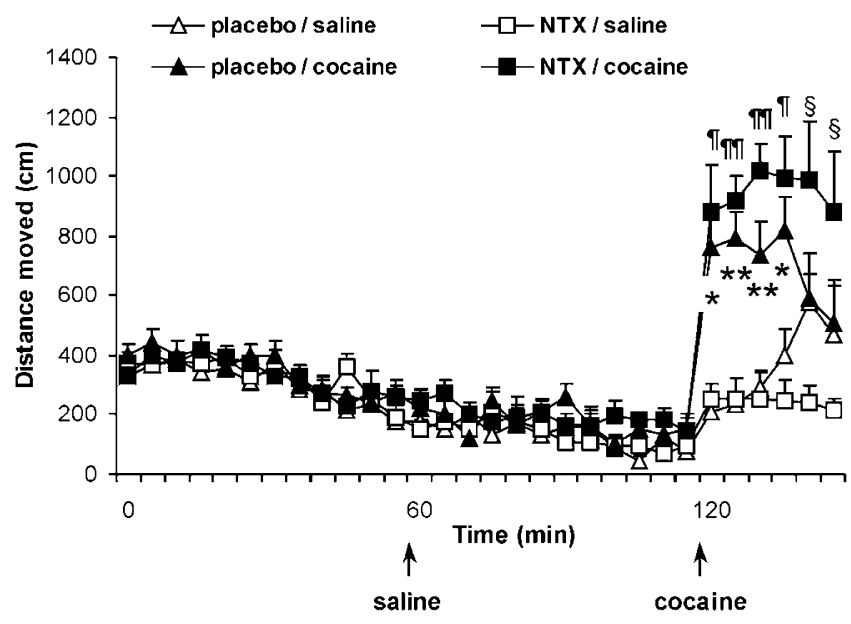

Figure 6 Effects of chronic placebo or NTX pretreatment upon the development of behavioral sensitization. Starting $48 \mathrm{~h}$ after placebo or NTX pellet removal, repeated intermittent daily injections of saline or cocaine $(20 \mathrm{mg} / \mathrm{kg})$ were given for II days. The time course of the activity in the open field, $72 \mathrm{~h}$ after cessation of the sensitization protocol, is shown with I $\mathrm{h}$ adaptation to the field, followed by I $\mathrm{h}$ in the field after an i.p. saline injection and $30 \mathrm{~min}$ after an i.p. injection of a $10 \mathrm{mg} / \mathrm{kg}$ cocaine challenge. The total distance moved in centimetres during $5 \mathrm{~min}$ intervals is shown. $N=8$ per treatment (saline or cocaine) per pretreatment (NTX or placebo). ${ }^{*} P<0.05$, ${ }^{*} * P<0.01$, significant difference between saline and cocaine treated mice within the placebo pretreated group. ${ }^{\circledR} P<0.05$, " $P<0.01,{ }^{\top} P<0.001$, significant difference between NTX pretreated, saline controls, and NTX pretreated, cocaine treated mice.

cocaine challenge of chronic NTX and placebo pretreated mice is depicted in Figure 6.

During the first hour in the open field the mice adapted to the open field, as reflected by a decrease in locomotor activity (effect of time $\mathrm{F}(11,308)=14, P<0.001$ ). There was no effect of chronic NTX pretreatment upon the locomotor activity during the first hour in the open field. The locomotor activity during the hour subsequent to saline injection declined further (effect of time: $\mathrm{F}(11,308)=3.7$, $P<0.001$ ), without group differences.

The cocaine-induced locomotor response was augmented in cocaine treated mice (effect of treatment $\mathrm{F}(1,28)=58$, $P<0.001)$. Chronic NTX pretreatment enhanced the development of behavioral sensitization to cocaine, which was apparent from a significant pretreatment $\times$ treatment interaction $(\mathrm{F}(1,28)=7.2, P<0.05)$. Separate analyses of the groups confirmed the development of cocaine-induced behavioral sensitization in placebo pretreated mice (time$\times$ treatment $\quad \mathrm{F}(5,70)=4.8, \quad P<0.01 \quad$ and treatment $\mathrm{F}(1,14)=10, P<0.01)$ and chronic NTX pretreated mice (treatment $\mathrm{F}(1,14)=62, \quad P<0.001)$. Post hoc analyses revealed that placebo/cocaine treated mice were significantly more active than placebo/saline treated mice during the first $20 \mathrm{~min}$ after cocaine challenge injection $(P<0.01)$. Across the entire $30 \mathrm{~min}$ after cocaine injection, the NTX pretreated mice that received repeated intermittent cocaine injections were significantly more active than NTX pretreated mice that received repeated saline injections $(P<0.01)$. Placebo/saline pretreated mice were more active as compared to chronic NTX/saline pretreated mice 20$25 \mathrm{~min}$ after injection of $10 \mathrm{mg} / \mathrm{kg}$ cocaine $(P<0.01)$.

\section{DISCUSSION}

Here we investigated the role of $\mu$-opioid receptors in the acute locomotor response to cocaine and in the development of cocaine-induced behavioral sensitization using $\mu$-opioid receptor knockout mice, co-administration of the $\mu$-opioid receptor antagonist CTOP, and chronic NTX pretreatment. Chronic NTX pretreatment is known to induce increases in $\mu$-opioid receptor binding, but also in $\delta$ - and $\kappa$-opioid receptor binding, although to a lesser extent (Lesscher et al, 2003). Our findings indicate that $\mu$-opioid receptors are not required for acute cocaine-induced locomotor activity nor are they essential for cocaineinduced behavioral sensitization to develop.

\section{Acute Cocaine-Induced Locomotor Activity}

The locomotor response to cocaine was not different between $\mu$-opioid receptor knockout and wild-type mice, suggesting that $\mu$-opioid receptors are not required for cocaine-induced motor activity. Similarly, no differences were apparent between chronic NTX pretreated mice and placebo pretreated controls, except for the response to $30 \mathrm{mg} / \mathrm{kg}$ cocaine. A significant pretreatment time interaction for this dose suggests a different temporal pattern of the response to $30 \mathrm{mg} / \mathrm{kg}$ cocaine between placebo and chronic NTX pretreated mice. Cocaine-induced locomotor activity has not been described previously for chronic NTX pretreated animals. With respect to $\mu$-opioid receptor knockout mice, the present findings are in agreement with those of Becker et al (2002) who also reported comparable cocaine-induced locomotor activity for $\mu$-opioid receptor knockout mice, which lack exons $2+3$ of the $\mu$-opioid receptor gene, and wild-type controls. Taken together, $\mu$ opioid receptors are not required for the acute locomotor response to cocaine in mice.

\section{Cocaine-Induced Behavioral Sensitization}

Opioid modulation of psychostimulant-induced behavioral sensitization has been described previously, at least for $\delta$ and $\kappa$-opioid receptors. The $\delta$-opioid receptor antagonist naltrindole and $\kappa$-opioid receptor selective agonists impaired the development of behavioral sensitization, which occurs after repeated intermittent treatment of rats with psychostimulant drugs (Heidbreder et al, 1993a,b, 1995, 1996; Shippenberg and Heidbreder, 1995b; Shippenberg et al, 1996; Shippenberg and Rea, 1997 but Vanderschuren et al, 2000). A role of $\mu$-opioid receptors in psychostimulant sensitization was suggested first of all by impaired cocaineinduced sensitization after NTX co-administered with cocaine (Sala et al, 1995) and also by findings of two recent studies. Expression of mRNA encoding $\mu$ - and $\delta$-opioid receptors was increased in the VTA of amphetaminesensitized rats (Magendzo and Bustos, 2003). Another study dealt with cocaine-induced behavioral sensitization in mice with a targeted deletion of exons 2 and 3 of the $\mu$-opioid receptor gene. These $\mu$-opioid receptor knockout mice developed a sensitized locomotor response to cocaine, although the temporal pattern of responding was different from wild-type mice (Yoo et al, 2003). 
The present data show that cocaine-induced behavioral sensitization is retained in exon $1 \mu$-opioid receptor knockout mice suggesting that $\mu$-opioid receptors are not required for cocaine-induced behavioral sensitization. However, inherent to application of classic knockout strategies and hence lack of a specific gene from gestation, the possibility that for example $\delta$-opioid receptors have compensated for the loss of $\mu$-opioid receptors in this case cannot be ruled out. Retained cocaine-induced behavioral sensitization for $\mu$-opioid receptor knockout mice is not in agreement with previous studies, which suggested a role of $\mu$-opioid receptors in psychostimulant sensitization (Sala et al, 1995; Magendzo and Bustos, 2003; Yoo et al, 2003). Therefore, a subsequent experiment was performed to elucidate the role of $\mu$-opioid receptors in cocaine-induced sensitization. For this experiment, the $\mu$-opioid receptor selective antagonist CTOP, which is approximately 2000fold more specific for $\mu$ - over $\delta$-opioid receptors (Hawkins et al, 1989), was co-administered with cocaine according to a procedure similar to the previous study by Sala et al (1995) with the nonselective opioid antagonist NTX. If $\mu$ opioid receptors were involved in cocaine-induced behavioral sensitization as the previous data of Sala et al (1995) suggest, then the $\mu$-opioid receptor selective antagonist CTOP should impair cocaine-induced behavioral sensitization. We did not observe a difference in cocaine-induced behavioral sensitization between CTOP and saline treated groups suggesting that in fact that $\mu$-opioid receptors are not required for behavioral sensitization to the locomotor stimulant effects of cocaine to develop, which is in agreement with the $\mu$-opioid receptor knockout experiment. In further support of a lack of involvement of $\mu$-opioid receptors in cocaine-induced behavioral sensitization, a recent study by Hummel et al (2004) reported cocaineinduced behavioral sensitization in exon $1 \mu$-opioid receptor knockout mice. As mentioned, Yoo et al (2003) reported differential cocaine-induced behavioral sensitization in $\mu$-opioid receptor knockout mice. They observed cocaine-induced behavioral sensitization in $\mu$-opioid receptor knockout mice, lacking exons 2 and 3, after 6 days of cocaine treatment whereas behavioral sensitization was only apparent after 12 days of cocaine treatment in wild-type controls. This suggests that cocaine-induced behavioral sensitization is potentiated in the absence of $\mu$-opioid receptors. However, the lack of cocaine-induced behavioral sensitization in wild-type mice on day 6 together with the fact that both at the first day of testing and after 6 days of cocaine treatment, the locomotor response to cocaine was lower for $\mu$-opioid receptor knockout mice as compared to wild-type controls complicate the interpretation of these data. Taken together, $\mu$-opioid receptors appear not to be required for the development of cocaine-induced behavioral sensitization.

In the final experiment the effect of overexpression of predominantly $\mu$-, but also $\delta$-, opioid receptors by chronic NTX pretreatment upon cocaine-induced behavioral sensitization was assessed. Chronic NTX pretreatment was found to augment cocaine-induced behavioral sensitization. This is an interesting finding considering that the acute locomotor response to cocaine was not affected by chronic NTX pretreatment, although at the $30 \mathrm{mg} / \mathrm{kg}$ dose the cocaine response appeared higher for mice that were pretreated with NTX as opposed to placebo pretreated controls. However, $\mu$-opioid receptors seem not to be required for cocaine-induced behavioral sensitization to develop, as can be concluded from the $\mu$-opioid receptor knockout and CTOP experiments, respectively. Therefore, it appears unlikely that enhanced $\mu$-opioid receptor levels in chronic NTX treated mice contribute to enhanced behavioral sensitization to the locomotor stimulant effects of cocaine in these mice. Rather, the augmented sensitized locomotor response to cocaine of chronic NTX pretreated mice may be attributable to increased number of $\delta$-opioid receptors, the subtype of opioid receptors that has indeed been implicated in cocaine-induced behavioral sensitization (Heidbreder et al, 1993a, 1996; Shippenberg and Heidbreder, 1995b).

In contrast to retained cocaine-induced behavioral sensitization observed for $\mu$-opioid receptor knockout mice, $\mu$-opioid receptor knockout mice failed to self-administer cocaine (Mathon et al, in preparation), suggesting that $\mu$ opioid receptors are critically involved in cocaine reinforcement but are not required for cocaine-induced behavioral sensitization. The sensitization protocol that was used for the present studies involved daily injections in an environment different from the test environment, similar to previous studies addressing the role of $\delta$ - and $\kappa$-opioid receptors in cocaine-induced behavioral sensitization (Heidbreder et al, 1995, 1996). With this approach mainly non-associative aspects of cocaine-induced behavioral sensitization are involved. It is therefore interesting to consider the possibility that $\mu$-opioid receptors might be involved in associative aspects of cocaine-induced behavioral sensitization, which could be subject to future studies. For chronic NTX treatment, a striking parallel increase is apparent in the development of cocaine-induced sensitization and cocaine reinforcement, both of which are augmented after chronic NTX pretreatment. Chronic treatment with NTX facilitated the initiation of cocaine self-administration in rats (Ramsey and Van Ree, 1990) and initiation of alcohol consumption has been shown to be potentiated by chronic NTX treatment in mice (Phillips et al, 1997). It appears that similar mechanisms might be involved in both phenomena. However, since chronic NTX treatment causes increases both in $\mu$ - and $\delta$-opioid receptor levels (Lesscher et al, 2003), the increased reinforcing effects of cocaine and the augmented cocaineinduced behavioral sensitization in chronic NTX pretreated mice are likely to entail distinct mechanisms, that is through increased $\mu$ - and $\delta$-opioid receptors, respectively.

In conclusion, the present findings show that $\mu$-opioid receptors are not required for the acute locomotor response to cocaine or for the development of cocaine-induced behavioral sensitization.

\section{ACKNOWLEDGEMENTS}

This work is supported by the Netherlands Organization for Scientific Research (ZON-MW grant 985-01-004). The Research Triangle Institute, through NIDA, USA, kindly provided the NTX and corresponding placebo pellets. The authors are grateful to JE Pintar and AGP Schuller for providing the $\mu$-opioid receptor knockout mice. 


\section{REFERENCES}

Becker A, Grecksch G, Kraus J, Loh HH, Schroeder H, Hollt V (2002). Rewarding effects of ethanol and cocaine in mu opioid receptor-deficient mice. Naunyn Schmiedebergs Arch Pharmacol 365: 296-302.

De Vry J, Donselaar I, Van Ree JM (1989). Food deprivation and acquisition of intravenous cocaine self-administration in rats: effect of naltrexone and haloperidol. J Pharmacol Exp Ther 251: 735-740.

Froehlich JC, Harts J, Lumeng L, Li TK (1990). Naloxone attenuates voluntary ethanol intake in rats selectively bred for high ethanol preference. Pharmacol Biochem Behav 35: 385-390.

Hawkins KN, Knapp RJ, Lui GK, Gulya K, Kazmierski W, Wan YP et al (1989). [ $\left.{ }^{3} \mathrm{H}\right]-[\mathrm{H}-\mathrm{D}-\mathrm{Phe}-\mathrm{Cys}-\mathrm{Tyr}-\mathrm{D}-\mathrm{Trp}-\mathrm{Orn}-\mathrm{Thr}-\mathrm{Pen}-\mathrm{Thr}-$ NH2] ( $\left.\left[{ }^{3} \mathrm{H}\right] \mathrm{CTOP}\right)$, a potent and highly selective peptide for mu opioid receptors in rat brain. $J$ Pharmacol Exp Ther 248: 73-80.

Heidbreder C, Goldberg SR, Shippenberg TS (1993a). Inhibition of cocaine-induced sensitization by the delta-opioid receptor antagonist naltrindole. Eur J Pharmacol 243: 123-127.

Heidbreder C, Shoaib M, Shippenberg TS (1996). Differential role of delta-opioid receptors in the development and expression of behavioral sensitization to cocaine. Eur J Pharmacol 298: 207-216.

Heidbreder CA, Babovic-Vuksanovic D, Shoaib M, Shippenberg TS (1995). Development of behavioral sensitization to cocaine: influence of kappa opioid receptor agonists. J Pharmacol Exp Ther 275: 150-163.

Heidbreder CA, Goldberg SR, Shippenberg TS (1993b). The kappaopioid receptor agonist U-69593 attenuates cocaine-induced behavioral sensitization in the rat. Brain Res 616: 335-338.

Herz A (1997). Endogenous opioid systems and alcohol addiction. Psychopharmacology (Berlin) 129: 99-111.

Horger BA, Shelton K, Schenk S (1990). Preexposure sensitizes rats to the rewarding effects of cocaine. Pharmacol Biochem Behav 37: 707-711.

Hummel M, Ansonoff MA, Pintar JE, Unterwald EM (2004). Genetic and pharmacological manipulation of $\mu$-opioid receptors in mice reveals a differential effect on behavioral sensitization to cocaine. Neuroscience 125: 211-220.

Kim SG, Stromberg MF, Kim MJ, Volpicelli JR, Park JM (2000). The effect of antagonists selective for mu- and delta-opioid receptor subtypes on alcohol consumption in C57BL/6 mice. Alcohol 22: 85-90.

Kornet M, Goosen C, Van Ree JM (1991). Effect of naltrexone on alcohol consumption during chronic alcohol drinking and after a period of imposed abstinence in free-choice drinking rhesus monkeys. Psychopharmacology (Berlin) 104: 367-376.

Kuzmin AV, Gerrits MAFM, Van Ree JM, Zvartau EE (1997). Naloxone inhibits the reinforcing and motivational aspects of cocaine addiction in mice. Life Sci 60: PL257-PL264.

Lesscher HMB, Bailey A, Burbach JP, Van Ree JM, Kitchen I, Gerrits MAFM (2003). Receptor-selective changes in $\mu$-, $\delta$ - and $\mathrm{k}$-opioid receptors after chronic naltrexone treatment in mice. Eur J Neurosci 17: 1006-1012.

Lett BT (1989). Repeated exposures intensify rather than diminish the rewarding effects of amphetamine, morphine, and cocaine. Psychopharmacology (Berlin) 98: 357-362.

Magendzo K, Bustos G (2003). Expression of amphetamineinduced behavioral sensitization after short- and long-term withdrawal periods: participation of $\mu$ - and delta-opioid receptors. Neuropsychopharmacology 28: 468-477.

Mathon DS, Lesscher HMB, Gerrits MAFM, Kamal A, Pintar JE, Schuller AGP et al (in preparation). Reduced cocaine reinforcement and increased GABAergic inhibition in the VTA of $\mu$-opioid receptor knockout mice.
Phillips TJ, Wenger CD, Dorow JD (1997). Naltrexone effects on ethanol drinking acquisition and on established ethanol consumption in C57BL/6J mice. Alcohol Clin Exp Res 21: 691-702.

Piazza PV, Deminiere JM, Le Moal M, Simon H (1990). Stress- and pharmacologically-induced behavioral sensitization increases vulnerability to acquisition of amphetamine self-administration. Brain Res 514: 22-26.

Ramsey NF, Gerrits MAFM, Van Ree JM (1999). Naltrexone affects cocaine self-administration in naïve rats through the ventral tegmental area rather than dopaminergic target regions. Eur Neuropsychopharmacol 9: 93-99.

Ramsey NF, Van Ree JM (1990). Chronic pretreatment with naltrexone facilitates acquisition of intravenous cocaine selfadministration in rats. Eur Neuropsychopharmacol 1: 55-61.

Robinson TE, Berridge KC (2000). The psychology and neurobiology of addiction: an incentive-sensitization view. Addiction 95(Suppl 2): S91-S117.

Sala M, Braida D, Colombo M, Groppetti A, Sacco S, Gori E et al (1995). Behavioral and biochemical evidence of opioidergic involvement in cocaine sensitization. J Pharmacol Exp Ther 274: 450-457.

Schuller AG, King MA, Zhang J, Bolan E, Pan YX, Morgan DJ et al (1999). Retention of heroin and morphine-6 beta-glucuronide analgesia in a new line of mice lacking exon 1 of MOR-1. Nat Neurosci 2: 151-156.

Shippenberg TS, Heidbreder C (1995a). Sensitization to the conditioned rewarding effects of cocaine: pharmacological and temporal characteristics. J Pharmacol Exp Ther 273: 808-815.

Shippenberg TS, Heidbreder C (1995b). The delta-opioid receptor antagonist naltrindole prevents sensitization to the conditioned rewarding effects of cocaine. Eur J Pharmacol 280: 55-61.

Shippenberg TS, LeFevour A, Heidbreder C (1996). kappa-Opioid receptor agonists prevent sensitization to the conditioned rewarding effects of cocaine. J Pharmacol Exp Ther 276: $545-554$.

Shippenberg TS, Rea W (1997). Sensitization to the behavioral effects of cocaine: modulation by dynorphin and kappa-opioid receptor agonists. Pharmacol Biochem Behav 57: 449-455.

Stromberg MF, Casale M, Volpicelli L, Volpicelli JR, O’Brien CP (1998). A comparison of the effects of the opioid antagonists naltrexone, naltrindole, and beta-funaltrexamine on ethanol consumption in the rat. Alcohol 15: 281-289.

Ungless MA, Whistler JL, Malenka RC, Bonci A (2001). Single cocaine exposure in vivo induces long-term potentiation in dopamine neurons. Nature 411: 583-587.

Van Ree JM, Gerrits MAFM, Vanderschuren LJ (1999). Opioids, reward and addiction: an encounter of biology, psychology, and medicine. Pharmacol Rev 51: 341-396.

Vanderschuren LJ, Schmidt ED, De Vries TJ, Van Moorsel CA, Tilders FJ, Schoffelmeer AN (1999). A single exposure to amphetamine is sufficient to induce long-term behavioral, neuroendocrine, and neurochemical sensitization in rats. J Neurosci 19: 9579-9586.

Vanderschuren LJ, Schoffelmeer AN, Wardeh G, De Vries TJ (2000). Dissociable effects of the kappa-opioid receptor agonists bremazocine, U69593, and U50488H on locomotor activity and long-term behavioral sensitization induced by amphetamine and cocaine. Psychopharmacology (Berlin) 150: 35-44.

Yoburn BC, Luke MC, Pasternak GW, Inturrisi CE (1988). Upregulation of opioid receptor subtypes correlates with potency changes of morphine and DADLE. Life Sci 43: 1319-1324.

Yoo JH, Yang EM, Lee SY, Loh HH, Ho IK, Jang CG (2003). Differential effects of morphine and cocaine on locomotor activity and sensitization in mu-opioid receptor knockout mice. Neurosci Lett 344: 37-40. 